\title{
Anti-Aging Activity of Cucurbita moschata Ethanolic Extract Towards NIH3T3 Fibroblast Cells Induced by Doxorubicin
}

\author{
Laeli Muntafiah, Bani Adlina Shabrina, Dwi Sulistyowati, Murah Riski Novi \\ Asshagab, Riris Istighfari Jenie*
}

Faculty of Pharmacy, Universitas Gadjah Mada, Yogyakarta, Indonesia

\begin{abstract}
Degenerative disease caused by decreasing organ function in old people has become the biggest death cause in the world. This aging process marked by senescence activity. An anti-aging agent from the medicinal plant has high potency to be developed, such as pumpkin seed (Cucurbita moschata) which contain tocopherol as antioxidant. The aim of this study is to investigate the anti-aging effect of pumpkin seed extract (PSE) on NIH 3T3 fibroblast normal cell induced by doxorubicin. This anti-aging effect was observed using MTT assay continued by SA-Bgal (Senescence-Associated Beta-Galactosidase) activity detection test. The stability of molecular interaction between tocopherol and doxorubicin to CYP 3A4 as the oxidase enzyme was conducted using molecular docking. Based on in vitro test, PSE is not cytotoxic to NIH 3T3. PSE at the dose of $100,200,400$, and 800 $\mu \mathrm{g} / \mathrm{mL}$ decreased $\%$ cell senescence by 2,$77 ; 4,5 ; 6$; and 18 times respectively. Meanwhile, in silico test indicated that tocopherol $(-107,409)$ has a higher interaction to CYP 3A4 compared to doxorubicin $(-70,52)$. Both compounds have a similar binding site in Leu 364; Phe 435; Pro 434; Cys 442; lle 369; Thr 309; dan Ala 305. The overall result of this study showed that PSE has anti-aging effect by decreasing SA- Bgal activity. This anti-aging activity possibly due to the interaction between tocopherol to CYP 3A4 based on molecular docking.
\end{abstract}

Keywords: anti-aging, Cucurbita moschata, tocopherol, SA-ßgal, molecular docking

\section{INTRODUCTION}

Degenerative disease is a non-infectious disease caused by cellular dysfunction, which has high correlation to aging process. According to WHO (2013), the mortality rate of degenerative disease is more than 36 million people every year. Almost $80 \%$ death caused by this disease occurred in developing country. More than 9 million deaths were caused by degenerative disease occurred on people under 60. Degenerative disease such as heart disease becomes the primary cause 17.3 million people every year, followed by cancer (6.7 million), respiratory disease (4.2 million) and diabetes (1.3 million) (WHO, 2013). Many efforts have been conducted to overcome problem this problem, such as the used of the antiaging agent as antioxidant. Antioxidant is a mechanism of the compound to protect cells against free radicals by stabilizing ROS that damage cells (Rahmi, 2011).
Pumpkin seeds (Curcubita moschata) is a medicinal plant with potency as an anti-aging agent. Pumpkin seeds contain many micronutrients such as vitamin A, B complex, $\mathrm{C}, \mathrm{D}, \mathrm{E}$ and $\mathrm{K}$. Vitamin E, such as tocopherol (Fig. 1), is a molecule with antioxidant activity to prevent cells damage (Gemrot, et al., 2006). Alfa-tocopherol and gamma-tocopherol could be found in pumpkin seed oil by $77.9 \pm 1.9 \mu \mathrm{g} / \mathrm{g}$ and $586 \pm 4.6 \mu \mathrm{g} / \mathrm{g}$ respectively (Butinar, et al., 2011). The aim of this study is to explore the potential of pumpkin seed extract (PSE) as an anti-aging agent. The anti-aging activity of pumpkin seed was performed by in vitro study to detect SA-Bgal (Senescence-Associated BetaGalactosidase) activity and in silico study by docking molecular. Based on this study, pumpkin seed can be developed as a potential anti-aging agent to solve aging problem leading to degenerative disease.

\footnotetext{
*Corresponding author email: ririsjenie@gmail.com
} 


\section{MATERIAL AND METHODS}

\section{Reagents}

Culture media components were DMEM high glucose (Gibco), Fetal Bovine Serum (FBS) 10\% (Gibco), Penicillin Streptomycin 1\% (Gibco), dan Trypsin EDTA $0,25 \%$. Samples were dissolved in DMSO (Sigma). Other reagents were doxorubicin (Sigma), PBS buffer : $\mathrm{NaCl}$, buffer phosphate, paraformaldehyde. X-gal solvent: X-gal, $\mathrm{K}_{3} \mathrm{Fe}[\mathrm{CN}]_{6}, \quad \mathrm{~K}_{4} \mathrm{Fe}[\mathrm{CN}]_{6} 3 \mathrm{H}_{2} \mathrm{O}, \quad \mathrm{MgCl}_{2} 6 \mathrm{H}_{2} \mathrm{O}$, PBS, aquabidest, X-Gaal fixation: formaldehyde, glutaraldehyde, aquabidest.

\section{Culture}

Fibroblast cell lines, NIH 3T3 (Cancer Chemoprevention Research Center Faculty of Pharmacy UGM collection) were cultured in Dulbecco's Modified Eagle's Medium (DMEM) supplemented with $10 \%$ fetal bovine serum $(\mathrm{FBS})$ at $37^{\circ} \mathrm{C}$ in $5 \% \mathrm{CO}_{2}$.

\section{Sample}

Pumpkin seeds were collected from Boyolali, Central Java and determined by Faculty of Pharmacy, UGM. Pumpkin seed was and dried, powdered, and extracted by soxhletation method using petroleum ether. The extract was evaporated using rotary evaporator. Profile of PSE as analyzed by thin layer chromatography.

\section{In vitro assay}

Cytotoxic assay was conducted by MTT assay. Anti-aging activity then performed by

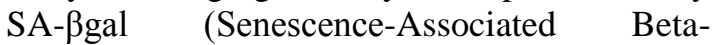
Galactosidase) activity. Antiaging activity was observed by the number of blue senescence cells through SA- $\beta$ gal method. Breast cancer cell 4T1 was used as negative control. NIH 3T3 cells were treated using doxorubicin to induced cells senescence. Cells senescence were observed by blue color at the $1^{\text {st }}, 4^{\text {th }}, 12^{\text {th }}, 16^{\text {th }}$ and $24^{\text {th }}$ hour using contrast phase microscope.

\section{Molecular Docking}

In silico assay by molecular docking was performed using PLANTS software by calculate RMSD (Root Mean Square Distances) heavy atom (ligand) score and copy ligand. Docking was conducted using native ligand, tocopherol, doxorubicin and each oxidation enzyme CYP3A4 and compared by each docking score.

\section{RESULT AND DISCUSSION}

\section{Qualitative Screening of Pumpkin Seed Extract's Components by TLC}

PSE which obtained by Soxhletation method was identified by using thin layer chromatography. The visible spots on the plate were quantified by using a densitometer. Based on the analysis, PSE contained $11.22 \mathrm{mg} / 100 \mathrm{~g}$ or $112.3 \mathrm{mg} / \mathrm{g}$. Pumpkin seed oil has strong antioxidant activity. 100 grams of pumpkin seed oil contained $80.65 \mathrm{mg}$ of tocopherol (Stevenson, et al., 2007).

\section{Cytotoxic Assay of PSE toward NIH3T3 Fibroblast Cell Line}

Normal NIH3T3 fibroblast cell line was distributed into 96-well plate, 1000 cells per well then incubated for 24 hours. PSE sample was dissolved in DMSO and diluted into 1$1000 \mu \mathrm{g} / \mathrm{mL}$. MTT reagent was added and incubated again until the purple formazan crystal was formed. Enzyme succinate dehydrogenase in mitochondria reacted with MTT to form purple complex of formazan crystal. MTT reaction was stopped by adding $10 \%$ SDS stopper reagent. Purple color intensity was measured using ELISA reader at $\lambda=595 \mathrm{~nm}$.<smiles>CC1=C2OC(C)(CCCC(C)CCCC(C)CCCC(C)C)CCC2=C(C)C(O)C1C</smiles>

Figure I. Structur of Tocopherol 


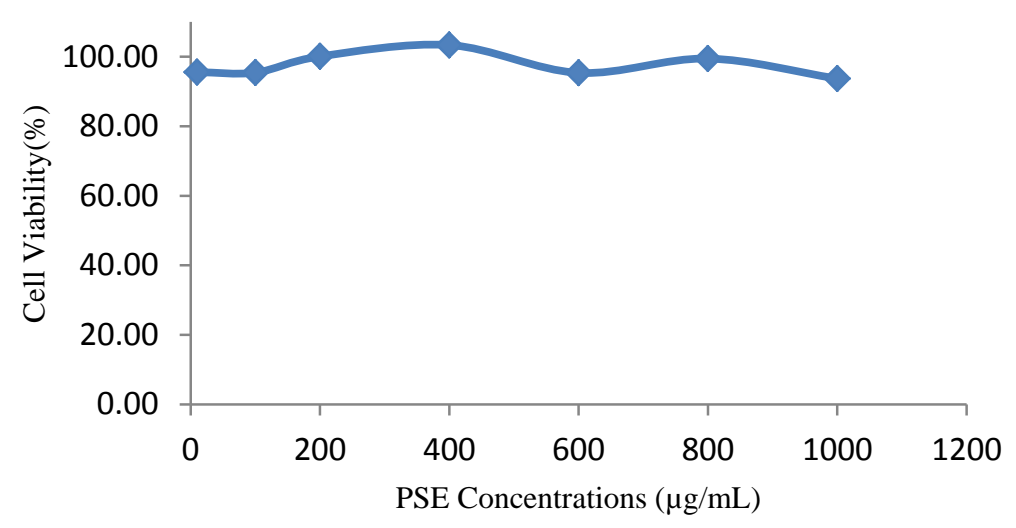

Figure 2. Cytotoxic activity of PSE in normal NIH3T3 fibroblast cell line

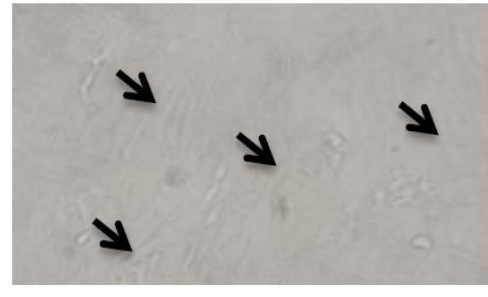

Kontrol Sel

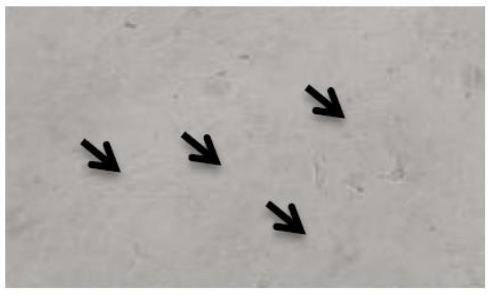

EBL $200 \mu \mathrm{g} / \mathrm{mL}$

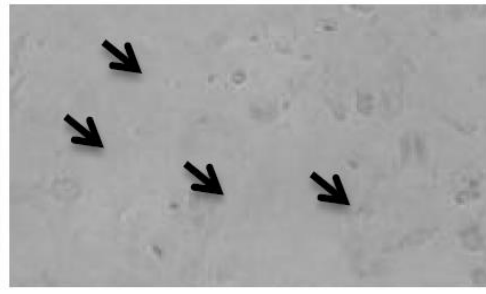

EBL $1000 \mu \mathrm{g} / \mathrm{mL}$

Figure 3. Morphology profile of NIH3T3 cell treated with PSE

The cytotoxic assay showed that PSE had no cytotoxic activity toward NIH3T3 cell line (Fig. 2 and 3). Based on Fig. 3, the concentration used in this treatment did not reduce cells viability. NIH3T3 cells treated with PSE showed same morphology compared to control cells. To observed cells senescence, NIH 3T3 cells was induced by doxorubicin. Doxorubicin will be metabolized by CYP3A4 oxidase enzyme into its metabolites that triggered cells to produce Reactive Oxygen Species (ROS) leading to cell senescence.

Doxorubicin at the concentration of 250 $\mathrm{ng} / \mathrm{mL}$ which had the cell viability was more than $80 \%$ was used to induce the senescence in SA- $\beta$ gal activity detection (Fig. 4). The cells reacted with X-gal reagent. The senescence cells produced beta-galactosidase which could be detected by the addition of X-gal. The reaction between $\mathrm{X}$-gal and this enzyme formed a blue color and observed at 1, 4, 12, 16, and 24 hours after staining. Figure 5 showed control cells which treated by doxorubicin was marked in blue and showed by red arrows. Treatment using PSE at various concentrations series performed antisenescence effect, which characterized by the absence of blue marked cells.

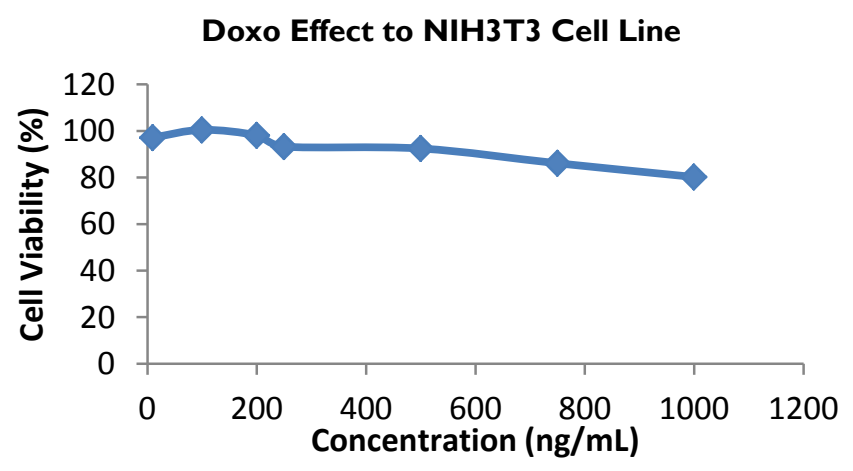

Figure 4. Optimation of Doxorubicin effects in NIH3T3 cell line 


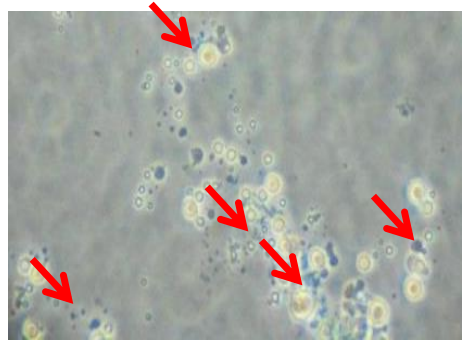

Cell control

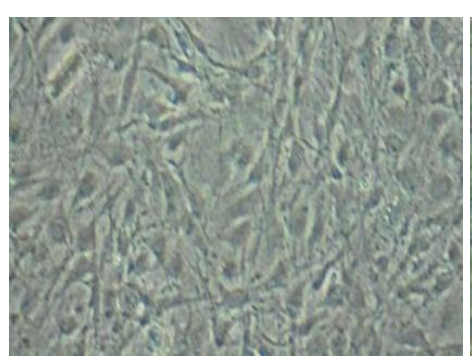

Cell control without doxorubicin

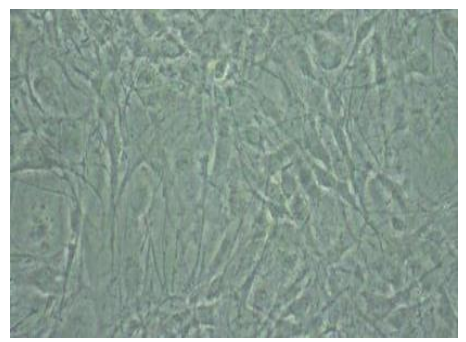

PSE $100 \mathrm{mg} / \mathrm{mL}$

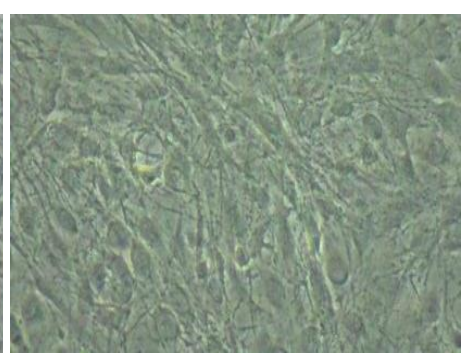

PSE $400 \mathrm{mg} / \mathrm{mL}$

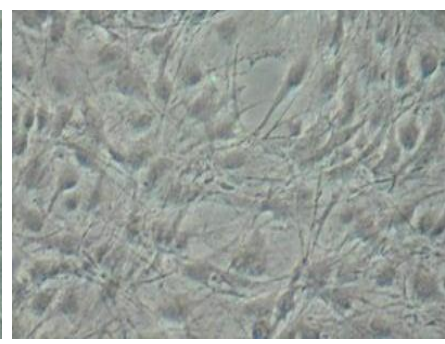

PSE $200 \mathrm{mg} / \mathrm{mL}$

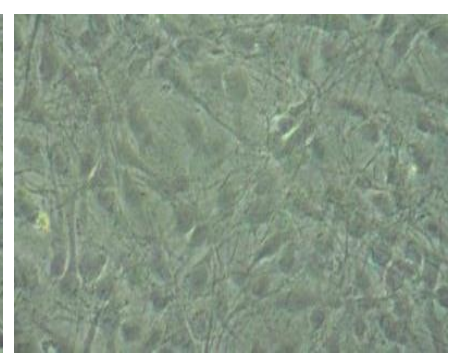

PSE $800 \mathrm{mg} / \mathrm{mL}$

Figure 5. SA- $\beta$ gal assay after PSE treatment

\section{Tocopherol Presenced in PSE was Abled to Compete in Interacting with CYP3A4}

Molecular docking was performed to predict the interaction ability of native ligand, tocopherol, and doxorubicin, with an oxidase enzyme CYP3A4. The docking score between the active compound of PSE (tocopherol) and the oxidase enzyme that (CYP3A4) indicated the strength of bonding between the ligand and receptor. The more negative value of docking score, exhibit a stronger and more stable bond. The stronger bond showed the higher potential of the compounds to developed as an anti-aging agent. Moreover, the docking visualization was conducted to determine the similarity of its connective sites using Moe software.
This docking score of CYP3A4 with $\alpha$ tocopherol and doxorubicin were -107.409 and -70.52 respectively. Docking score of $\alpha$ tocopherol that interacted with CYP3A4 was lower than doxorubicin- CYP3A4. The binding affinity between protein oxidation CYP3A4 toward $\alpha$-tocopherol was greater than doxorubicin. Docking visualization results indicated there were similar connective sites on the amino acid residues of Leu 364; Phe 435; Pro 434; Cys 442; Ile 369; Thr 309; and Ala 305 of native protein-ligand, protein- $\alpha-$ tocopherol, and protein-doxorubicin. Thus, tocopherol in PSE could compete with the native ligand to interact with CYP3A4.

Table I. Docking Score of CYP3A4 in Interaction with $\alpha$-Tocopherol-Doxorubicin

\begin{tabular}{ll}
\hline \multicolumn{1}{c}{ CYP3A4 vs $\alpha$-Tocopherol-Doxorubicin } \\
\hline RMSD & $2,1793^{\circ} \mathrm{A}$ \\
& \\
& \\
& $\alpha-T o c o p h e r o l$ \\
Doxorubicin & -107.409 \\
Ligand Native - Ritonavir & -70.52 \\
\hline
\end{tabular}




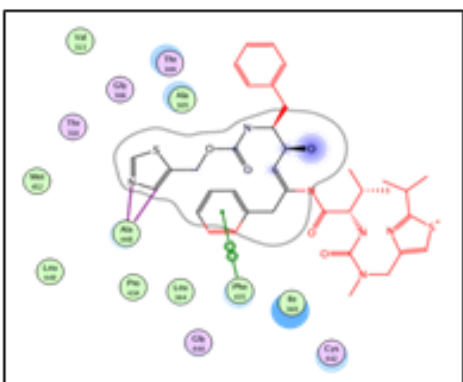

Protein - Ligand Native

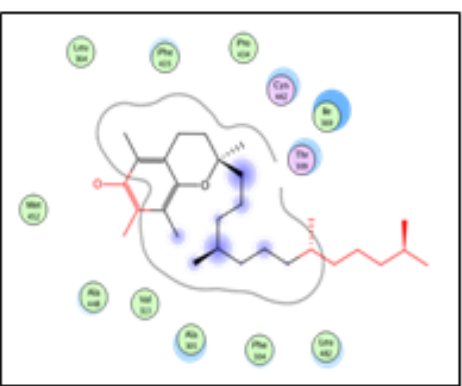

Protein - a-Tocopherol

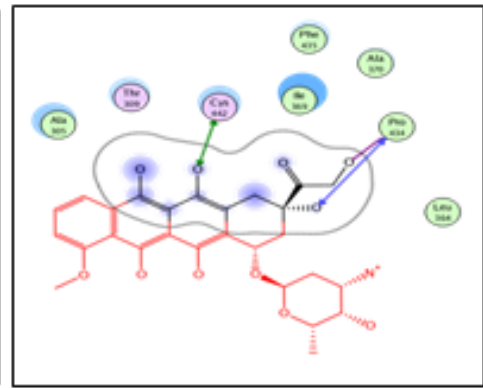

Protein - Doxorubicin

Figure 6. Docking Visualization of the interaction between Ligand Native, $\alpha$-tocopherol, and Doxorubicin to CYP3A4

\section{CONCLUSION}

Based on this study, PSE had no cytotoxic activity to normal NIH3T3 fibroblast cells and reduced the senescence activity of cells. PSE could be developed as an antiaging agent to prevent of degenerative diseases. Further research is needed to determine the molecular mechanism of senescence inhibitory activity on normal NIH3T3 fibroblast cells by PSE.

\section{ACKNOWLEDGEMENT}

We would like to thank to DIKTI, which had funded this study, along with Chemoprevention Cancer Research Center (CCRC), Faculty of Pharmacy UGM. 